\title{
ANALISIS DATA MINING UNTUK PEMETAAN MAHASISWA YANG MEMBUTUHKAN BIMBINGAN DAN KONSELING MENGGUNAKAN ALGORITMA NAÏVE BAYES CLASSIFIER
}

\author{
Hadi Kurnia Saputra ${ }^{1}$
}

\begin{abstract}
The students' success on educational process in the university can be measured through academic performance and study completion. However, on the students' educational process can't be separated from a variety of problems, both from the environmental education and family and also social environment. One of the efforts made by educational institutions to encourage low students' academic performance are to provide guidance and counseling services. Data Mining can be done with the classification of students who have good and bad academic performance. Naïve Bayes Classifier Algorithm is chosen to perform Classification of student slow academic performance and assessed that they need Guidance and Counseling process. A study of 507 records of student academic datasets Sign 2008 Strata-1 program of the Faculty of Engineering, State University of Padang, Naïve Bayes algorithm is able to classify students who need Guidance and Counseling process. Based on the tests performed on the students of Engineering Studies Program representing that all of them obtained an accuracy of $81 \%$.
\end{abstract}

Keywords :Guidance and Counseling, Data Mining, Academic Performance, Classification, Naïve Bayes Classifier

\section{INTISARI}

Keberhasilan mahasiswa dalam menjalani proses pendidikan di Perguruan Tinggi dapat diukur melalui kinerja akademik dan masa penyelesaian studi. Namun, dalam perjalanan mahasiswa mengikuti proses pendidikan tidak bisa lepas dari berbagai permasalahan, baik yang bersumber dari lingkungan pendidikan maupun lingkungan keluarga dan pergaulan. Salah satu upaya yang dilakukan oleh institusi pendidikan untuk mendorong peningkatan kinerja akademik mahasiswa yang rendah adalah dengan memberikan pelayanan Bimbingan dan Konseling (BK). Dengan Data Mining dapat dilakukan klasifikasi mahasiswa yang memiliki kinerja akademik yang baik dan buruk. Algoritma Naïve Bayes Classifier dipilih untuk melakukan klasifikasi mahasiswa yang berkinerja akademik rendah dan dinilai membutuhkan proses Bimbingan dan Konseling. Penelitian yang dilakukan terhadap 507 record set data akademik mahasiswa Tahun Masuk 2008 program Strata-1 Fakultas Teknik Universitas Negeri Padang, algoritma Naïve Bayes mampu mengklasifikasi mahasiswa yang membutuhkan proses Bimbingan dan Konseling. Berdasarkan pengujian yang dilakukan terhadap mahasiswa Fakultas Teknik yang mewakili keseluruhan Program Studi diperoleh akurasi sebesar 81\%.

Kata Kunci : Bimbingan dan Konseling, Data Mining, Kinerja Akademik, Klasifikasi, Naïve Bayes Classifier 


\section{PENDAHULUAN}

Pemasalahan akademik yang sering dihadapi oleh perguruan tinggi adalah permasalahan prestasi akademik mahasiswa yang rendah. Dalam perjalanan mahasiswa menuntut ilmu tidak akan luput dari masalah yang dihadapi baik masalah akademik maupun non akademik. Masalah-masalah tersebut dapat mempengaruhi tidak tercapainya prestasi optimal mahasiswa, atau salah satu indikator yang dapat dilihat dialaminya masalah oleh mahasiswa adalah dengan pencapain Indeks Prestasi (IP) yang rendah, atau dibawah ratarata [7].

Melalui teknik Data Mining, data akademik dapat dimanfaatkan untuk memperoleh informasi prestasi akademik, masa studi serta tingkat kelulusan mahasiswa. Data-data tersebut dapat diolah lebih lanjut untuk memetakan mahasiswa yang berpotensi menerima sanksi akademik, selanjutnya pihak manajemen dapat mengambil kebijakan dan tindakan untuk mangantisipasi hal tersebut. Salah satu tindakan yang dapat dilakukan adalah dengan memberikan layanan bimbingan dan konseling kepada setiap mahasiswa yang berpotensi dikenakan sanksi akademik.

\section{PENDEKATAN}

\section{MASALAH}

Knowledge Discovery in Database Knowledge Discovery in

Database (KDD) adalah penerapan metode saintifik pada Data Mining. Dalam konteks ini Data Mining merupakan satu langkah dari proses KDD [6].

KDD adalah kegiatan atau proses untuk mendapatkan informasi yang meliputi pengumpulan, pemakaian data historis untuk menemukan keteraturan, pola dan hubungan dalam set data berukuran besar. Fungsi-fungsi dalam Data Mining antara lain fungsi deksripsi, estimasi, prediksi, klasifikasi, klasterisasi dan asosiasi.

KDD merupakan keseluruhan proses konversi data mentah menjadi pengetahuan yang bermanfaat yang terdiri dari serangkaian tahap transformasi meliputi data preprocessing dan postprocessing. Data preprocessing merupakan langkah awal untuk mengubah data mentah menjadi format yang sesuai untuk tahap analisis selanjutnya. Data preprocessing kemungkinan akan membutuhkan waktu yang sangat lama, hal ini dikarenakan data yang mentah kemungkinan disimpan dengan format dan database yang berbeda. Sedangkan Postprocessing meliputi semua operasi yang harus dilakukan agar hasil Data Mining dapat diakses dan lebih mudah diinpretasikan oleh para pihak analisis [10].

\section{Data Mining}

Data Mining sebenarnya merupakan bagian dari proses Knowledge Discovery in Database (KDD), bukan sebagai teknologi yang utuh dan berdiri sendiri. Data Mining merupakan salah satu bagian langkah yang penting dalam proses KDD terutama berkaitan dengan ekstraksi dan penghitungan polapola dari data yang ditelaah. Adapun tahapan atau rangkaian proses Data Mining dapat dibagi menjadi beberapa tahap. Tahap-tahap tersebut bersifat iterative. Terdapat 7 tahapan pada Data Mining, yaitu [1] : 


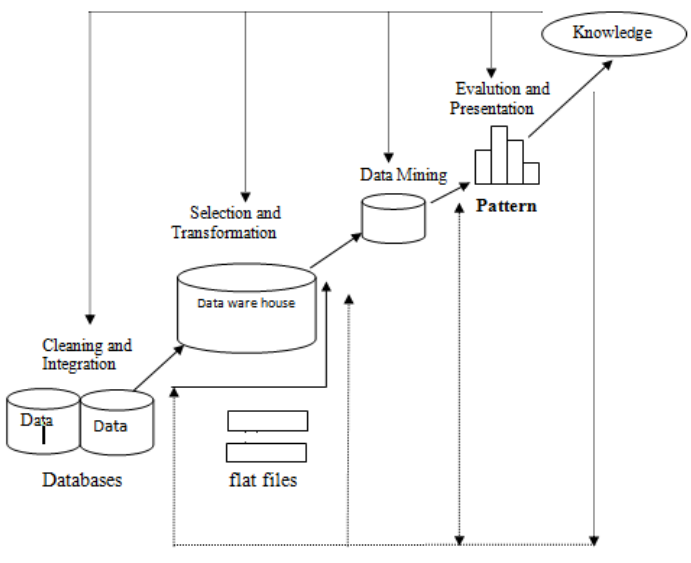

Gambar 1. Tahapan Data Mining Tahapan-tahapan Data Mining seperti gambar 1 dapat dijelaskan sebagai berikut :

a. Data Cleaning

Membersihkan data dari data yang tidak konsisten dan bersifat noise karena secara umum data yang tersedia pada database memiliki isian-isian yang tidak sempurna karena hilang ataupun tidak valid. Selain itu, ada juga karakteristik data yang tidak relevan dengan kebutuhan untuk Data Mining.

b. Data Integration

Mengintegrasikan data dari berbagai sumber, dimana integrasi ini dilakukan pada data-data yang memiliki atribut unik. Pada proses integrasi perlu dilaksanakan dengan hatihati karena kesalahan dapat mengakibatkan hasil yang menyimpang.

c. Data Selection

Data yang ada pada database sering kali tidak semuanya dipakai, oleh karena itu hanya data yang sesuai untuk dianalisis yang akan diambil dari database.

d. Data Transformation

Mentransformasikan data supaya sesuai untuk kebutuhan Data Mining. Aturan pemrograman untuk mengenali pola dari data untuk pelaksanaan transformasi ini sering disebut dengan algoritma. Beberapa algoritma Data Mining yang populer seperti : Association Rule, KMeans Clustering, C.45, Naïve Bayes Classfier, Apriori, Tree Structured, dan lain-lain. Masing-masing algoritma ini akan menghasilkan output yang berbeda-beda.

e. Proses Mining

Merupakan suatu proses utama saat metode diterapkan untuk menemukan pengetahuan berharga dan tersembunyi dari data.

f. Pattern Evaluation

Evaluasi atas pola yang ditemukan berguna untuk menemukan informasi emas (knowledge). Pada tahapan ini diharapkan adanya hasil berupa pola yang unik yang dapat digunakan sebagai model untuk memprediksi perilaku-perilaku bisnis yang sekiranya akan mempengaruhi sebuah keputusan manajemen.

g. Knowledge Presentation Mempresentasikan knowledge yang sudah didapatkan dari user. Tahapan terakhir ini merangkum dan menerjemahkan analisa yang telah didapat dengan bahasa yang semudah mungkin karena melibatkan orang lain pada manajemen yang kemungkinan besar awam dengan Data Mining.

\section{Teknik Klasifikasi Data Mining}

Klasifikasi Data Mining adalah suatu metode pembelajaran, untuk memprediksi nilai dari sekelompok atribut dalam menggambarkan dan membedakan kelas data atau konsep yang bertujuan untuk memprediksi kelas dari objek yang label kelasnya tidak diketahui [9].

Klasifikasi merupakan suatu fungsionalitas Data Mining yang akan menghasilkan model untuk 
memprediksi kelas atau kategori dari objek-objek di dalam basis data. Klasifikasi merupakan proses yang terdiri dari dua tahap, yaitu tahap pembelajaran dan tahap pengklasifikasian. Pada tahap pembelajaran, sebuah algoritma klasifikasi akan membangun sebuah model klasifikasi dengan cara menganalisis training data. Tahap pembelajaran dapat juga dipandang sebagai tahap pembentukan fungsi atau pemetaan $Y=F(X)$ di mana $Y$ adalah kelas hasil prediksi dan $X$ adalah tuple yang ingin diprediksi kelasnya.

Data Classification memiliki dua tahap proses. Tahap pertama adalah membangun suatu model yang berdasarkan serangkaian data class yang disebut learned model. Model tersebut dibangun dengan menanalisa database tuple. Setiap tuple diasumsikan menjadi predefined class yang ditentukan oleh satu atribut yang disebut class label attribute. Akibat terdapat class label maka tahap ini juga dikenal dengan supervised learning [2].

Teknik klasifikasi merupakan pendekatan untuk menjalankan fungsi klasifikasi dalam Data Mining yaitu untuk menggolongkan data. Teknik klasifikasi ini dapat pula digunakan untuk melakukan prediksi atas informasi yang belum diketahui sebelumnya. Beberapa algoritma yang dapat digunakan antara lain adalah algoritma Decission Tree C.45, Artificial Neural Networks (ANN), K-Nearest Neighbor (KNN), algoritma Naive Bayes, Neural Network serta algoritma lainnya.

\section{Algoritma Naive Bayes Classifier}

Algoritma Naive Bayes merupakan salah satu algoritma yang terdapat pada teknik klasifikasi. Naive Bayes merupakan pengklasifikasian dengan metode probabilitas dan statistik yang dikemukan oleh ilmuwan Inggris
Thomas Bayes, yaitu memprediksi peluang di masa depan berdasarkan pengalaman dimasa sebelumnya sehingga dikenal sebagai Teorema Bayes. Teorema tersebut dikombinasikan dengan Naive dimana diasumsikan kondisi antar atribut saling bebas. Klasifikasi Naive Bayes diasumsikan bahwa ada atau tidak ciri tertentu dari sebuah kelas tidak ada hubungannya dengan ciri dari kelas lainnya [4].

Naïve Bayes Classifier merupakan salah satu algoritma dalam teknik Data Mining yang menerapkan teori Bayes dalam klasifikasi. Teorema keputusan Bayes adalah adalah pendekatan statistik yang fundamental dalam pengenalan pola (pattern recoginition) [8]. Naive bayes didasarkan pada asumsi penyederhanaan bahwa nilai atribut secara konditional saling bebas jika diberikan nilai output. Dengan kata lain, diberikan nilai output, probabilitas mengamati secara bersama adalah produk dari probabilitas individu.

Bentuk umum dari teorema Bayes sebagai berikut :

$P(Y \mid X)=\frac{P(X \mid Y) \cdot P(Y)}{P(X)}$

Di mana :

\begin{tabular}{|c|c|}
\hline$x$ & $\begin{array}{l}\text { :Data dengan class yang } \\
\text { belum diketahui }\end{array}$ \\
\hline$Y$ & $\begin{array}{l}\text { Hipotesis data } X \\
\text { merupakan suatu class } \\
\text { spesifik }\end{array}$ \\
\hline$P(Y \mid X)$ & $\begin{array}{lr}\text { Probabilitas } & \text { akhir } \\
\text { bersyarat } & \text { (conditional } \\
\text { probability) } & \text { suatu } \\
\text { hipotesis } Y & \text { terjadi jika } \\
\text { diberikan } & \text { bukti } \\
\text { (evidence) } X \text { terjadi. }\end{array}$ \\
\hline$P(Y)$ & $\begin{array}{lr}\text { Probabilitas awal } & \text { aw } \\
\text { (priori) hipotesis } Y \\
\text { terjadi tanpa } \\
\text { mengandung bukti } \\
\text { apapun. }\end{array}$ \\
\hline
\end{tabular}




$P(X \mid Y) \quad$ : Probabilitas sebuah
bukti $X$ terjadi akan
mempengaruhi
hipotesis $Y$.
$P(X) \quad$ Probabilitas awal
(priori) bukt $X$ terjadi
tanpa mengandung
hipotesis/bukti yang
lain.

Kaitan antara Naïve Bayes dengan klasifikasi, korelasi hipotesis, dan bukti dengan klasifikasi adalah bahwa hipotesis dalam teorema Bayes merupakan label kelas yang menjadi target pemetaan dalam klasifikasi, sedangkan bukti merupakan fitur-fitur yang menjadi masukan dalam model klasifikasi [5].

Jika $X$ adalah vektor masukan yang berisi fitur dan $Y$ adalah label kelas, Naïve Bayes dituliskan dengan $P(Y \mid X)$. Notasi tersebut berarti probabilitas label kelas $Y$ didapatkan setelah fitur-fitur $X$ diamati. Notasi ini disebut juga probabilitas akhir (posterior probability) untuk $Y$, sedangkan $P(Y)$ disebut probabilitas awal (prior probability) $Y$.

Formulasi Naïve Bayes untuk klasifikasi adalah :

$$
P(Y \mid X)=\frac{P(Y) \Pi_{i=1}^{q} P\left(X_{i} \mid Y\right)}{P(X)}
$$

$\begin{array}{ll}P(X / Y) & \begin{array}{l}\text { : Probabilitas data } \\ \text { dengan vector } X \\ \text { pada kelas } Y . \\ \end{array} \\ P(Y) & \begin{array}{l}\text { Probabilitas } \\ \text { kelas } Y .\end{array} \\ \Pi_{i=1}^{q} P\left(X_{i} \mid Y\right) \quad \text { Probabilitas }\end{array}$

independen kelas $Y$ dari semua fitur dalam vektor $X$.

Nilai $P(X)$ selalu tetap sehingga dalam perhitungan prediksi nantinya tinggal menghitung bagian $P(Y) \Pi_{i=1}^{q} P\left(X_{i} \mid Y\right)$ dengan memilih yang terbesar sebagai kelas yang dipilih sebagai hasil prediksi. Sementara probabilitas independen $\Pi_{i=1}^{q} P\left(X_{i} \mid Y\right)$ tersebut merupakan pengaruh semua fitur dari data terhadap setiap kelas $Y$, yang dinotasikan dengan :

$P(X \mid Y=y)=\Pi_{i=1}^{q} P\left(X_{i} \mid Y=\right.$

y)

\section{3)}

Setiap set fitur $X=$ $\left\{X_{1}, X_{12}, X_{3}, \ldots \ldots, X_{q}\right\}$ terdiri atas $q$ atribut ( $q$ dimensi).

Naive Bayes Classifier mengestimasi peluang kelas bersyarat dengan mengasumsikan bahwa atribut adalah independen secara bersyarat yang diberikan dengan label kelas $y$. Asumsi independen bersyarat dapat dinyatakan dalam bentuk berikut :

$$
P(X \mid Y=y)=\prod_{i=1}^{d} P\left(X_{i} \mid Y=y\right)
$$

Dengan tiap set atribut $X=\left\{X_{1}, X_{2}, \ldots, X_{d}\right\}$ terdiri dari $d$ atribut. Atribut kategorikal, peluang bersyarat $\quad P\left(X_{i}=x_{i} \mid Y=y\right)$ diestimasi menurut pecahan training instances pada kelas $y$ yang membuat nilai atribut khusus $x_{i}$.

Distribusi Gaussian sering dipillh untuk merepresentasikan peluang kelas bersyarat untuk atribut kontinyu. Distribusi dikarakterisasi dengan dua parameter yaitu mean, $\mu$, dan varian, $\sigma^{2}$. Untuk tiap kelas $y_{j}$, peluang kelas bersyarat untuk atribut $X_{i}$ adalah :

$$
P\left(X_{i}=x_{i} \mid Y=y_{j}\right)=\frac{1}{\sqrt{2 \pi} \sigma_{i j}} \exp ^{-\frac{\left(x_{i}-\mu_{i j}\right)^{2}}{2 \sigma^{2}}}
$$

Parameter $\mu_{i j}$ dapat diestimasi berdasarkan sampel mean $X_{i}(\bar{x})$ untuk seluruh training record yang 
dimiliki kelas $y_{j}$. Dengan cara sama, $\sigma_{i j}^{2}$ dapat diestimasi dari sampel varian $\left(s^{2}\right)$ training record tersebut.

\section{Bimbingan Konseling}

Bimbingan adalah membantu pemecahan masalah seseorang sehingga dapat membuat keputusan yang tepat atau dengan kata dengan bimbingan diharapkan memperoleh sebuah solusi dan perencanaan yang tepat [12]. Konseling adalah suatu proses wawancara yang bertujuan untuk memberikan bantuan kepada seseorang sehingga orang yang dilayani dapat lebih berkembang dalam kehidupannya [3]

Bimbingan Konseling merupakan proses pemberian bantuan yang dilakukan melalui wawancara konseling (face to face) oleh seorang ahli (disebut konselor) kepada individu yang sedang mengalami sesuatu masalah (disebut konseli) yang bermuara pada teratasinya masalah yang dihadapi konseli serta dapat memanfaatkan berbagai potensi yang dimiliki dan sarana yang ada, sehingga individu atau kelompok individu itu dapat memahami dirinya sendiri untuk mencapai perkembangan yang optimal, mandiri serta dapat merencanakan masa depan yang lebih baik untuk mencapai kesejahteraan hidup.

\section{ANALISA DAN PERANCANGAN Analisa Sistem}

Analisis sistem dilakukan untuk mengetahui faktor-faktor apa saja yang mempengaruhi sistem. Faktorfaktor tersebut yang akan dijadikan sebagai acuan dalam proses pengembangan sistem selanjutnya.

Berdasarkan hasil observasi dan wawancara yang dilakukan dengan pihak-pihak terkait dalam penentuan kriteria mahasiswa yang membutuhkan proses bimbingan dan konseling yang menjadi domain utama dari penelitian ini, belum ada ketentuan baku dan aturan khusus yang mengharuskan seorang mahasiswa harus mengikuti proses bimbingan dan konseling.

Setelah melakukan analisis dan identifikasi permasalahan pada sistem yang sedang berjalan, diperlukan adanya sebuah pola yang terotomasi oleh sistem untuk penentuan kriteria mahasiswa yang membutuhkan proses bimbingan konseling dengan memaksimalkan pemberdayaan set data akademik mahasiswa yang tersedia pada database akademik.

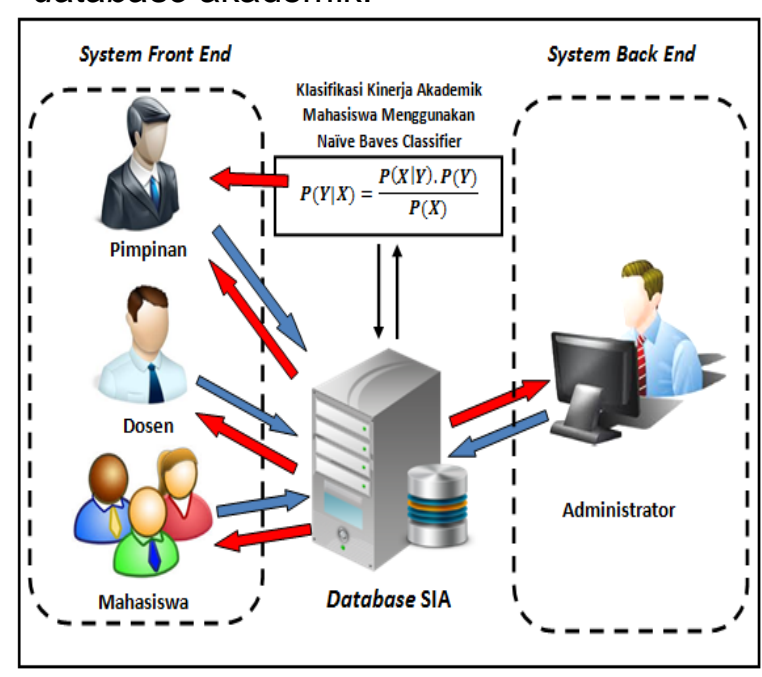

Gambar 2. Arsitektur Sistem yang Diusulkan

\section{Analisa Data Mining}

Teknik Data Mining yang digunakan dalam penelitian ini adalah teknik Classification. Sedangkan algoritma yang akan digunakan adalah Naive Bayes Classifier, sehingga analisa yang dilakukan mengacu kepada kebutuhan analisi algoritma Naive Bayes Classifier.

1. Pengumpulan Data Awal

Penelitian dilakukan menggunakan set data akademik mahasiswa program studi sarjana (S1) Fakultas Teknik 
Universitas Negeri Padang. Sampel data yang digunakan adalah data akademik mahasiswa tahun masuk 2008 semua program studi yang ada di Fakultas Teknik. Pemilihan sampel data ini didasarkan pada aspek kelengkapan data serta relevansinya dengan topik penelitian.

2. Mendeskripsikan Data

Set data akademik mahasiswa yang digunakan dalam penelitian ini terdiri dari data profil mahasiswa, orang tua, sekolah asal (SMTA), indeks prestasi dan kelulusan. Data-data tersebut dinilai bisa digunakan untuk penelitian yang berkaitan dengan kinerja akademik mahasiswa. Data-data tersebut terekam dalam bentuk tabel-tabel pada database akademik UNP.

3. Evaluasi Kualitas Data

Hasil evaluasi terhadap kualitas data yaitu menemukan banyak nilai kosong/null yang disebut dengan missing value pada atribut dalam set data akademik mahasiswa. Dari 507 record data terdapat 12 record yang memiliki atribut bernilai kosong/null, sedangkan 495 record memiliki atribut yang sudah memiliki data lengkap. Data yang memiliki atribut bernilai kosong/null.

Record yang memiliki nilai atribut kosong/null atau record missing value adalah

$\frac{12}{507} \times 100 \%=2.36 \%$. Sedangkan

data yang memiliki nilai atribut yang lengkap adalah : $\frac{495}{507} \times 100 \%=97.63 \%$.

4. Pemilihan Atribut Set data akademik mahasiswa yang digunakan dalam penelitian ini terdiri dari beberapa atribut antara lain : Angkatan/Tahun Masuk, Nama Mahasiswa, Jenis Kelamin, Status (aktif, cuti, lulus),
Program Studi, Status Masuk, Jenis SMTA, Pekerjaan Orang Tua (Ayah), IP Semester 1, IP Semester 2, IP Semester 3, IP Semester 4, Masa Studi.

Pemilihan atribut ini didasarkan pada faktor kebutuhan data yang relevan dengan topik penelitian dengan mempertimbangkan kelengkapan dan ketersediaan data pada database akademik.

\section{Persiapan Data (Data Preparation)}

Persiapan data mencakup semua kegiatan untuk membangun set data akademik mahasiswa yang akan diterapkan ke dalam sistem, dari data mentah awal berupa set data akademik mahasiswa selanjutnya akan melakukan proses data mining dan akan diterukan dengan proses klasifikasi menggunakan algoritma Naive Bayes Classifier.

1. Seleksi Data (Data Selection)

Atribut yang digunakan adalah ID MHS, Nama, Jenis Kelamin, Status Wisuda, Program Studi, Jenjang Program, Status Masuk, Jenis SMTA, Pekerjaan Ayah, IP Sem 1, IP Sem 2, IP Sem 3, IP Sem 4 dan Masa Studi.

Dari seluruh program studi Strata 1 Fakultas Teknik UNP yaitu Program Studi Pendidikan Teknik Bangunan, Pendidikan Teknik Elektro, Pendidikan Teknik Elektronika, Pendidikan Teknik Informatika dan Komputer, Pendidikan Teknik Mesin, Pendidikan Teknik Otomotif serta Pendidikan Kesejahteraan Keluarga, diperoleh data sebanyak 507 record. Data tersebut akan dibagi menjadi dua bagian untuk keperluan data training dan data testing. Pengambilan data yang akan digunakan sebagai data training pada proses Data Mining didasarkan pada teknik 
pengambilan sampel penelitian. Jika populasi $>100$ objek maka dapat diambil $10 \%-15 \%$ atau $20 \%-25 \%$ dari semua jumlah populasi. Jika populasi $<100$ objek maka diambil seluruh dari populasi sebagai sampel penelitian [11]. Jika sampel untuk data training diambil sebanyak $10 \%$ dari 507 record data, maka data yang akan digunakan sebagai data training adalah sebanyak 51 record. Sedang sisanya sebanyak 456 record akan digunakan sebagai data testing.

2. Pengolahan Data Mentah (Data Preprosessing/ Data Cleaning) Tahap ini merupakan tahap untuk memastikan data akademik mahasiswa yang dipilih telah layak untuk dilakukan proses pengolahan. Data Cleaning dilakukan ketika terlihat data yang tidak konsisten atau data tersebut ganda. Proses Cleaning data dapat dilakukan dengan cara :

1) Menambahkan isi atribut yang kosong secara manual

2) Menghapus data yang ganda secara manual

Kedua cara tersebut tidak efektif kalau digunakan pada data yang banyak.

3. Transformasi Data (Data Transformation)

Transformasi data diberlakukan untuk atribut/parameter yang harus diubah dulu ke format sesuai kategorinya. Transformasi data dilakukan secara manual pada data yang akan diolah. Data yang berjenis numerikal seperti Masa Studi harus dilakukan proses inisialisasi data terlebih dahulu ke dalam bentuk kategorikal.
Tabel 1. Transformasi Data

\begin{tabular}{|c|c|c|c|c|c|}
\hline \multirow{2}{*}{$\begin{array}{l}\mathbf{N} \\
\mathbf{0}\end{array}$} & \multicolumn{2}{|c|}{ Kondisi Awal } & \multicolumn{2}{|c|}{ Transformasi } & \multirow[b]{2}{*}{ Keterangan } \\
\hline & $\begin{array}{c}\text { Atribu } \\
t\end{array}$ & $\begin{array}{c}\text { Kategor } \\
\text { i }\end{array}$ & $\begin{array}{c}\text { Atribu } \\
\mathbf{t}\end{array}$ & Kategori & \\
\hline 1 & $\begin{array}{l}\text { Status } \\
\text { Wisuda }\end{array}$ & $\begin{array}{l}\text { A = } \\
\text { Aktif } \\
\mathrm{C}=\text { Cuti } \\
\mathrm{L}= \\
\text { Lulus }\end{array}$ & $\begin{array}{l}\text { Status } \\
\text { Wisuda }\end{array}$ & $\begin{array}{l}B=\text { Belum } \\
\text { Lulus } \\
\mathrm{L}=\text { Lulus }\end{array}$ & $\begin{array}{l}\text { Satus Aktif dan } \\
\text { Cuti } \\
\text { dikategorikan } \\
\text { menjadi Belum } \\
\text { Lulus }\end{array}$ \\
\hline 2 & $\begin{array}{l}\text { Masa } \\
\text { Studi }\end{array}$ & $\begin{array}{l}\text { Range } 1 \\
\text { s.d. } 14 \\
\text { (Dalam } \\
\text { satuan } \\
\text { Semeste } \\
\text { r) }\end{array}$ & $\begin{array}{l}\text { Butuh } \\
\text { BK } \\
\text { (Bimbi } \\
\text { ngan } \\
\text { Konseli } \\
\text { ng) }\end{array}$ & $\begin{array}{l}\text { Tidak }= \\
\text { Masa studi } \leq \\
10 \text { Semester } \\
\text { Ya = masa } \\
\text { studi } \geq 11 \\
\text { Semester. }\end{array}$ & $\begin{array}{l}\text { Masa studi yang } \\
\text { telah dilalui } \\
\text { mahasiswa baik } \\
\text { yang belum lulus } \\
\text { maupun sudah } \\
\text { lulus } \\
\text { Atribut ini yang } \\
\text { akan dijadikan } \\
\text { sebagai dasar } \\
\text { dalam } \\
\text { menentukan } \\
\text { apakah } \\
\text { mahasiswa } \\
\text { membutuhkan } \\
\text { layanan } \\
\text { bimbingan dan } \\
\text { konseling. }\end{array}$ \\
\hline 3 & $\begin{array}{l}\text { IP } \\
\text { Semester } \\
1 \text { sampa } \\
4\end{array}$ & $\begin{array}{l}\text { Range } \\
0.0 \\
\text { sampai } \\
\text { dengan } \\
4.0\end{array}$ & $\begin{array}{l}\text { IP } \\
\text { Semeste } \\
\mathrm{r}\end{array}$ & & $\begin{array}{l}\text { Indeks prestasi } \\
\text { mahasiswa yang } \\
\text { bernilai numeric }\end{array}$ \\
\hline
\end{tabular}

\section{Klasifikasi dengan Naive Bayes Classifier}

1. Pemilihan Data Latih (Data Training)

Data training diambil secara acak (random) dari set data akademik mahasiswa yang sudah ditransformasi. Pengambilan data secara acak dapat dilakukan dengan membangkitkan bilangan random. Data training diambil sebanyak 51 record dan sampel dipilih secara acak dari semua data mahasiswa Fakultas Teknik UNP semua jenjang program. Data yang diambil hanya data akademik masiswa tahun masuk 2008.

a. Menghitung Probabilitas Setiap Fitur dan Kelas

Langkah awal yang dilakukan adalah menghitung nilai setiap fitur pada setiap kelasnya menggunakan teorema Bayes. Data yang digunakan adalah Data training. Untuk menghitung probabilitas setiap fitur, digunakan rumus $P(X / C i)$ untuk $\mathrm{i}=1,2$. Hasil perhitungan 
probabilitas setiap fitur dan kelas sebagai berikut :

1) Kelas Butuh BK :

Probabilitas kelas Butuh BK "YA" adalah P(Butuh BK "Ya") = $21 / 51=0.4118$

Probabilitas kelas Butuh BK "Tidak" adalah P(Butuh BK "Tidak") = 21/51 = 0.58082 .

2) Fitur Jenis Kelamin :

$P\left(\right.$ Jenis Kelamin $=L \mid$ Butuh BK $\left.=Y_{a}\right)=16 / 21=0.7619$

$P($ Jenis Kelamin $=P \mid$ Butuh BK $=Y a)=5 / 21=0.2381$

$P($ Jenis Kelamin $=\mathrm{L} \mid$ Butuh BK $=$ Tidak $)=19 / 30=0.6333$

$\mathrm{P}($ Jenis Kelamin $=\mathrm{P} \mid$ Butuh BK $=$ Tidak $)=11 / 30=0.3667$

3) Fitur Status Wisuda :

$P\left(\right.$ Status Wisuda $=L \mid$ Butuh BK $\left.=Y_{a}\right)=6 / 21=0.2857$

$P\left(\right.$ Status Wisuda $=P \mid$ Butuh BK $\left.=Y_{a}\right)=15 / 21=0.7143$

$P($ Status Wisuda $=\mathrm{L} \mid$ Butuh BK $=$ Tidak $)=28 / 30=0.9333$

$P($ Status Wisuda $=$ P $\mid$ Butuh BK $=$ Tidak $)=2 / 30=0.667$

4) Fitur Program Studi :

$P\left(\right.$ Prodi $=$ Bangunan $\mid$ Butuh $\left.B K=Y_{a}\right)=5 / 21=0.2381$

$P\left(\right.$ Prodi $=$ Elektro $\mid$ Butuh BK $\left.=Y_{a}\right)=6 / 21=0.2857$

$P\left(\right.$ Prodi $=$ Elektronika $\mid$ Butuh BK $\left.=Y_{a}\right)=4 / 21=0.1905$

$P\left(\right.$ Prodi $=$ Informatika $\mid$ Butuh BK $\left.=Y_{a}\right)=1 / 21=0.0476$

$P\left(\right.$ Prodi $=$ Mesin $\mid$ Butuh BK $\left.=Y_{a}\right)=0 / 21=0.0000$

$P\left(\right.$ Prodi $=$ Otomatif $\mid$ Butuh BK $\left.=Y_{a}\right)=2 / 21=0.0952$

$P\left(\right.$ Prodi $=$ PKK $\mid$ Butuh BK $\left.=Y_{a}\right)=3 / 21=0.1429$

$P($ Prodi $=$ Bangunan $\mid$ Butuh BK $=$ Tidak $)=4 / 30=0.1333$

$P($ Prodi = Elektro $\mid$ Butuh BK = Tidak $)=3 / 30=0.1000$

$\mathrm{P}($ Prodi $=$ Elektranika $\mid$ Butuh BK $=$ Tidak $)=6 / 30=0.2000$

$P($ Prodi $=$ Infarmatika | Butuh BK $=$ Tidak $)=6 / 30=0.2000$

$P($ Prodi $=$ Mesin $\mid$ Butuh BK $=$ Tidak $)=5 / 30=0.1667$

$P($ Prodi $=$ Dtomotif $\mid$ Butuh BK $=$ Tidak $)=4 / 30=0.1333$

$P($ Prodi $=$ PKK $\mid$ Butuh BK $=$ Tidak $)=2 / 30=0.0667$

5) Fitur Status Masuk :

$P\left(\right.$ Status Masuk $=$ PMDK/Undangan $\mid$ Butuh BK $\left.=Y_{a}\right)=6 / Z 1$ $=0.2857$

$P\left(\right.$ Status Masuk $=$ SPMB $/$ SNMPTN $\mid$ Butuh BK $\left.=Y_{a}\right)=2 / 21=$ 0.052

$P\left(\right.$ Status Masuk $=$ Non Reguler $\mid$ Butuh BK $\left.=Y_{a}\right)=13 / 21=$ 0.6190

$P($ Status Masuk $=$ PMDK/Undangan $\mid$ Butuh BK $=$ Tidak $)=$ $8 / 30=0.2667$

$P($ Status Masuk $=$ SPMB $/$ SNMPTN $\mid$ Butuh BK $=$ Tidak $)=$ $8 / 30=0.2667$

$P($ Status Masuk $=$ Non Reguler $\mid$ Butuh BK $=$ Tidak $)=14 / 30=$ 0.4667

6) Fitur Jenis SMTA :

$P\left(\right.$ Jenis SMTA $=$ SMU| Butuh BK $\left.=Y_{a}\right)=7 / 21=0.3333$

$P\left(\right.$ Jenis SMTA $=$ SMK $\mid$ Butuh $\left.B K=Y_{a}\right)=10 / 21=0.4762$

$P\left(\right.$ Jenis SMTA $=$ MA $\mid$ Butuh BK $\left.=Y_{a}\right)=1 / 21=0.0476$

$P\left(\right.$ Jenis SMTA $=$ SMTA lain-lain| Butuh BK $\left.=Y_{a}\right)=3 / 21=$ 0.1429

$P($ Jenis SMTA $=$ SMU| Butuh BK $=$ Tida $)=9 / 30=0.3000$

$P$ (Jenis SMTA $=$ SMK| Butuh BK $=$ Tidak $)=6 / 30=0.2000$

$P($ Jenis SMTA $=$ MA| Butuh BK $=$ Tidak $)=0 / 30=0.0000$

$P($ Jenis SMTA $=$ SMTA lain-lain $\mid$ Butuh BK $=$ Tidak $)=15 / 30=$ 0.5000

7) Fitur Pekerjaan Ayah :

$P\left(\right.$ Pekerjaan Ayah $=$ Dosen $/$ Gurul Butuh BK $\left.=Y_{a}\right)=1 / 21=$ 0.0476
P(Pekerjaan Ayah = Karyawan Swasta| Butuh BK = Ya $)=1 / 21$ $=0.0476$

P(Pekerjaen Ayah $=$ Pegawai Negeri| Butuh BK $\left.=Y_{a}\right)=8 / 21=$ 0.3810

$\mathrm{P}\left(\right.$ Pekerjaan Ayah $=$ Pensiunan| Butuh $\left.B K=Y_{a}\right)=2 / Z 1=$ 0.0952

P(Pekerjaan Ayah $=$ Petani/Nelayan| Butuh BK $\left.=Y_{a}\right)=1 / 21=$ 0.0476

$P\left(\right.$ Pekerjaan Ayah $=T N \mid / P$ oril Butuh BK $\left.=Y_{a}\right)=\square / Z 1=$ 0.0000

P(Pekerjaan Ayah $=$ Wiraswasta $\mid$ Butuh BK $\left.=Y_{a}\right)=6 / 21=$ 0.2857

$P\left(\right.$ Pekerjaan Ayah $=$ Lain-lain $\mid$ Butuh $\left.B K=Y_{a}\right)=2 / 2 \mid=$ 0.0952

P(Pekerjaan Ayah $=$ Dosen $/$ Guru $\mid$ Butuh BK $=$ Tidak $)=1 / 30$ $=0.0333$

P(Pekerjaan Ayah = Karyawan Swasta $\mid$ Butuh BK $=$ Tidak $)=$ 2/30 = 0.0667

$\mathrm{P}($ Pekerjaan Ayah $=$ Pegawai Negeri $\mid$ Butuh BK = Tidak $)=$ $3 / 30=0.1000$

P(Pekerjaan Ayah $=$ Pensiunan $\mid$ Butuh BK $=$ Tidak $)=1 / 30=$ 0.0333

$\mathrm{P}($ Pekerjaan Ayah $=$ Petani $/$ Nelayan $\mid$ Butuh BK $=$ Tidak $)=$ $6 / 30=0.2000$

P(Pekerjaan Ayah $=$ TNI $/$ Polri| Butuh BK $=$ Tidak $)=3 / 30=$ 0.1000

P(Pekerjaan Ayah $=$ Wiraswasta| Butuh BK $=$ Tidak $)=10 / 30$ $=0.3333$

$P($ Pekerjaan Ayah $=$ Lain-lain| Butuh BK $=$ Tidak $)=4 / 30=$ 0.1333

8) Fitur IP Semester 1:

$\bar{X}_{\text {Butuh } B K^{\prime \prime} \mathrm{Ya}^{\mathrm{m}}}=2.2862$

$S_{B \text { utuh } B K^{\prime \prime} Y a^{m}}^{2}=0.5383$

$S_{\text {Butuh } B K^{1} Y a^{m}}=0.7337$

$\bar{X}_{\text {Butwh BK "Tidak" }}=3.0623$

$S_{\text {Butwh } B K^{\prime} \text { "Tidak" }}^{2}=0.2184$

$S_{\text {Butuh BK }}{ }^{\text {Tidak" }}=0.4674$

9) Fitur IP Semester 2 :

$\bar{X}_{\text {Butwh } B K^{\prime \prime} \mathrm{Ya}^{\mathrm{m}}}=2.1933$

$S_{B \text { utuh } B K}^{2}{ }^{\prime \prime} \mathrm{Ya}^{\mathrm{m}}=0.6014$

$S_{B \text { utuh } B K}{ }^{\prime \prime} \mathrm{Ya}^{\mathrm{I}}=0.7755$

$\bar{X}_{\text {Butuh BK "Tidak" }}=2.8590$

$S_{\text {Butwh BK }}^{2}{ }^{\text {Tidak }}{ }^{n}=0.3038$

$S_{\text {Butuh } B K}$ "Tidak" $=0.5512$

10) Fitur IP Semester 3 :

$\bar{X}_{\text {Butuh } B K}{ }^{" \mathrm{Ya}^{\mathrm{I}}}=2.0586$ 


$$
\begin{aligned}
& S_{\text {Butuh } B K}^{2}{ }^{~ "} \mathrm{Ya}^{\mathrm{m}}=0.6042 \\
& \mathrm{~S}_{\text {Butuh BK }} \text { "Ya" }=0.7773 \\
& \overline{\mathrm{X}}_{\text {Butuh BK }}{ }^{\text {Tidakk }}{ }^{\mathrm{n}}=2.7867 \\
& \mathrm{~S}_{\text {Butuh BK "Tidak" }}^{2}=0.4326 \\
& \mathrm{~S}_{\text {Butuh BK "Tidak" }}=0.6577
\end{aligned}
$$

11) Fitur IP Semester 4 :

$$
\begin{aligned}
& \bar{X}_{\text {Butuh } B K^{\prime \prime} \mathrm{Ya}^{\mathrm{I}}}=1.8976 \\
& \mathrm{~S}_{\text {Butuh BK }}^{2}{ }^{\text {"Ya" }}=0.3966 \\
& \mathrm{~S}_{\text {Butuh BK }}{ } \mathrm{Ya}^{\mathrm{m}}=0.6298 \\
& \overline{\mathrm{X}}_{\text {Butuh BK }} \text { "Tidak" }^{n}=2.8233 \\
& \mathrm{~S}_{\text {Butuh BK "Tidak" }}^{2}=0.2923 \\
& \mathrm{~S}_{\text {Butuh BK "Tidak" }}=0.5406
\end{aligned}
$$

b. Menghitung Probabilitas Akhir Setiap Kelas

Misalkan akan dihitung probabilitas akhir menggunakan sebuah contoh data training ID MHS $=200807060$ dengan nilai fitur Jenis Kelamin $=P$, Status Wisuda $=\mathrm{B}$, Program Studi $=$ Pendidikan Kesejahteraan Keluarga, Status Masuk = SPMB/SNMPTN, Jenis SMTA = SMK, Pekerjaan Ayah $=$ Wiraswasta, $\mathrm{IP}$ Sem $1=2.24, \mathrm{IP}$ Sem $2=2.0$, IP Sem $3=1.86$, IP Sem $4=2.2$.

Berikut adalah tahapan penyelesaiannya :

1) Harus diketahui nilai probabilitas setiap fitur pada setiap kelasnya, menggunakan rumus $P(X i \mid Y j)$.

Nilai probabilitas setiap fitur mengacu kepada nilai yang telah diperoleh rincian sebagai berikut :

$P\left(\right.$ Jenis Kelamin $=P \mid$ Butuh $\left.B K=Y_{a}\right)=0.2381$

$P($ Jenis Kelamin $=\mathrm{P} \mid$ Butuh BK $=$ Tidak $)=036667$

$P\left(\right.$ Status Wisuda $=B \mid$ Butuh BK $\left.=Y_{a}\right)=0.7143$

$P($ Status Wisuda $=\mathrm{B} \mid$ Butuh BK $=$ Tidak $)=0.0667$

$P\left(\right.$ Prodi $=$ PKK $\mid$ Butuh BK $\left.=Y_{a}\right)=0.1429$

P(Prodi $=$ PKK $\mid$ Butuh BK = Tidak $)=0.0667$

$P\left(\right.$ Status Masuk $=$ SPMB $/$ SNMPTN $\mid$ Butuh BK $\left.=Y_{a}\right)=0.0952$

$P($ Status Masuk $=$ SPMB $/$ SNMPTN $\mid$ Butuh BK $=$ Tidak $)=0.2667$

$P\left(\right.$ Jenis SMTA $=$ SMK $\mid$ Butuh BK $\left.=Y_{a}\right)=0.4762$

$P($ Jenis SMTA $=$ SMK $\mid$ Butuh BK $=$ Tidak $)=0.2000$
$P\left(P\right.$ ekerjaan Ayah = Wiraswasta $\mid$ Butuh BK $\left.=Y_{a}\right)=0.2857$

$P($ Pekerjaan Ayah = Wiraswasta $\mid$ Butuh BK $=$ Tidak $)=0.3333$

Nilai probabilitas untuk fitur dengan tipe numerik yakni fitur IP Sem 1, IP Sem 2, IP Sem 3 dan IP Sem 4 dihitung menggunakan rumus :

Probabilitas IP Sem 1 :

Diketahui :

$$
\begin{aligned}
& \bar{X}_{\text {Butuh } B K^{*} \mathrm{Ya}^{\mathrm{p}}}=2.2862 \\
& S_{\text {Dutuh } B K^{\mathrm{s}} \mathrm{Ya}^{\mathrm{s}}}^{2}=0.5383 \\
& S_{\text {Butuh BK }}{ }^{{ }^{*} \mathrm{Ya}^{*}}=0.7337 \\
& \bar{X}_{\text {Butuh BK"Tidak" }}=3.0623 \\
& S_{\text {Butuh BN" Tidak" }}^{2}=0.2184 \\
& S_{\text {Butwh BN" }} \text { Tidak" }=0.4674
\end{aligned}
$$

P(IP Sem I = 2.24 | Butuh BK "Ya"

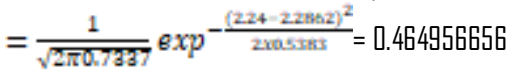

P(IP Sem | = 2.24 | Butuh BK "Tidak"

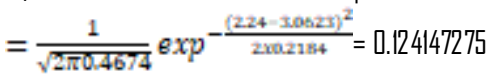

Probabilitas IP Sem 2 :

Diketahui :

$$
\begin{aligned}
& \bar{X}_{\text {Butuh } B K^{\text {"Ta }}}=2.1933
\end{aligned}
$$

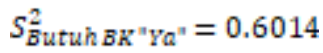

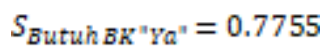

$$
\begin{aligned}
& \bar{X}_{\text {Butuh BK"Tidak" }}=2.8590 \\
& S_{\text {Dutuh BK" Tidak" }}^{2}=0.3038 \\
& S_{\text {Butuh BR }} \text { Tidak }=0.5512 \\
& \text { P(IP Sem } 2=2 \text { | Butuh BK "Ya" }
\end{aligned}
$$

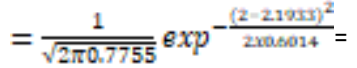

$$
\begin{aligned}
& 0.439264892 \\
& \text { P(IP Sem Z = } 2 \text { | Butuh BK "Tidak" }
\end{aligned}
$$

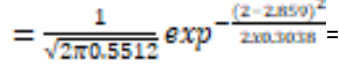

$$
\begin{aligned}
& 0.159598066
\end{aligned}
$$

Probabilitas IP Sem 3 :

$$
\text { Diketahui : }
$$

$\bar{X}_{\text {Butuh } B K^{T} \mathrm{YL}^{\mathrm{p}}}=2.0586$

$S_{\text {Eutuh } B K^{s} \mathrm{Ya}^{\mathrm{s}}}^{2}=0.6042$

$S_{\text {Butuh } B K^{\sigma^{*}} \mathrm{Ya}^{\mathrm{N}}}=0.7773$

$\bar{X}_{\text {Butuh } B K^{\text {"Tidak }}}=2.7867$

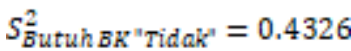

$S_{\text {Butuh } B K^{*}{ }^{*} \text { Tidak" }}=0.6577$

$\mathrm{P}(\mathrm{PP}$ Sem $4=1.86$ | Butuh BK "Ya"

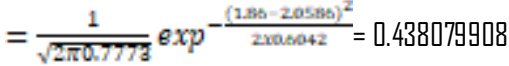




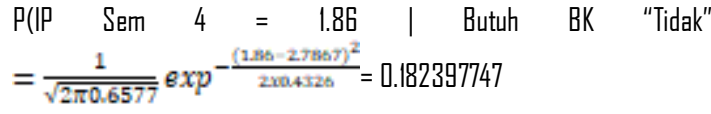

Probabilitas IP Sem 4 :

Diketahui :

$\bar{X}_{\text {Butuh } B K}$ "Ya" $=1.8976$

$S_{\text {Butuh } B K^{\mathrm{S}} \mathrm{Ya}^{\mathrm{*}}}^{2}=0.3966$

$S_{\text {Butuh } B K^{5} \mathrm{Ya}^{\mathrm{s}}}=0.6298$

$\bar{X}_{\text {Butuh BK"Tidak" }}=2.8233$

$S_{\text {Butuh BK }}^{2}$ Tidak" $^{2}=0.2923$

$S_{\text {ButuhBK }}$ "Tidak" $=0.5406$

$\mathrm{P}(\mathrm{P}$ Sem $4=2.2$ | Butuh BK "Ya"

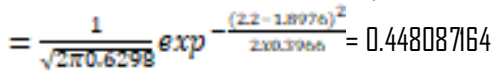

P(IP Sem $4=2.2$ | Butuh BK "Tidak"

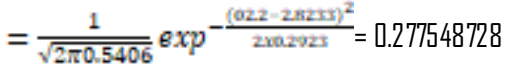

2) Langkah berikutnya adalah menghitung probabilitas akhir untuk setiap kelas :

$P\left(X \mid\right.$ Buth $\left.B K=Y_{a}\right)=P($ Jenis Kelamin $=P \mid$ Butuh $\left.B K=Y_{a}\right) \times P($ Status Wisuda $=B$ Butuh BK = Ya $) \times$ P(Prodi $=$ PKK I Butuh BK $\left.=Y_{a}\right) \times P($ Status Masuk = SPMB/SNMPTN | Butuh BK $\left.=Y_{a}\right) x$ $P\left(\right.$ Jenis SMTA $=$ SMK | Butuh BK $\left.=Y_{a}\right)$ x P(Pekerjaan Ayah = Wiraswasta Butuh BK = Ya $) \times P(I P$ Sem I = 2.24 | Butuh BK = Ya) $\times$ P (IP Sem $2=2.0$ | Butuh BK $\left.=Y_{a}\right) \times P($ IP Sem $3=1.86$ Butuh BK $\left.=Y_{a}\right) \times P(I P$ Sem $4=2.2$ | Butuh BK $=\gamma_{a}$ )

$=0.2381 \times 0.7143 \times 0.1429 \times 0.0952 \times$ $0.4762 \times 0.2857 \times 0.464956656 \times$ $0.439264892 \times 0.438079908 \times$ 0.448087164 $=0.0000126213$

$P(X \mid B u t h B K=$ Tidak $)=P($ Jenis Kelamin $=P \mid$ Butuh BK = Tidak $) \times P($ Status Wisuda $=\mathrm{B}$ Butuh BK = Tidak $) \times$ P(Prodi $=$ PKK I Butuh BK = Tidak $) \times P($ Status Masuk = SPMB/SNMPTN | Butuh BK = Tidak) $x$ $P($ Jenis SMTA = SMK | Butuh BK = Tidak) $\times$ P(Pekerjaan Ayah = Wiraswasta $\mid$ Butuh BK = Tidak) $\mathrm{x}$ P(IP Sem I = 2.24 | Butuh BK = Tidak) $x$ P(IP Sem $2=2 . D \mid$ Butuh BK = Tidak) $x$ P(IP Sem $3=1.86$ | Butuh BK = Tidak) $x$ P(IP Sem $4=2.2$ | Butuh $B K=$ Tidak)

$=0.3667 \times 0.0667 \times 0.0667 \times 0.2667$ $\times 0.2000 \times 0.0333 \times 0.124147275 \times$

\section{$0.159598066 \times 0.182397747 \times$ 0.277548728 \\ $=0.0000000291$}

a. Selanjutnya nilai tersebut dimasukkan untuk mendapatkan probabilitas akhir :

$P\left(B u t u h B=Y_{a} \mid X\right)=\alpha \times 0.4118 \times$ 0.0000126213

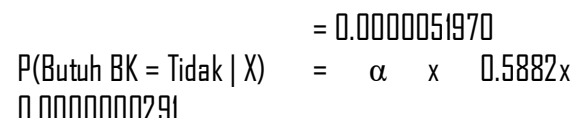
$=0.0000000171$

$\alpha=1 / P(X)$ nilainya konstan sehingga tidak perlu diketahui karena yang terbesar dari dua kelas tersebut tidak dapat dipengaruhi oleh $\mathrm{P}(\mathrm{X})$. Karena nilai probabilitas akhir terbesar ada di kelas Butuh BK "Ya", data uji mahasiswa NIM 200807060 diprediksi sebagai kelas Butuh BK "Ya". Hasil pengujian atas nama Sesri Noviarlis NIM 200807060 dapat dilihat pada Tabel 2 berikut :

Tabel 2. Hasil Klasifikasi

\begin{tabular}{|c|c|c|c|c|}
\hline \multirow{2}{*}{ ID MHS } & Nama & $\begin{array}{c}\text { Kelas: } \\
\text { Butuh }\end{array}$ & $\begin{array}{c}\text { Prediksi } \\
\text { Nä̃ve }\end{array}$ & Hasil \\
& & BK & Bayes & \\
\hline 200807060 & Sesri Noviarlis & $Y_{a}$ & $Y_{a}$ & AKLURAT \\
\hline
\end{tabular}

Data mahasiswa tersebut diambil dari data testing dan masuk ke kategori yang membutuhkan proses bimbingan dan konseling. Setelah dilakukan perhitungan menggunakan Naïve Bayes Classifier hasilnya adalah masuk kelas Butuh BK "Ya". Hasil pengujian yang diperoleh adalah AKURAT. 


\section{IMPLEMENTASI DAN PENGUJIAN}

Berdasarkan pengujian yang telah dilakukan dengan berbagai variasi, diperoleh hasil seperti terangkum pada Tabel 3 berikut :

Tabel 3 Rangkuman Hasil Pengujian

\begin{tabular}{|c|c|c|c|c|c|c|c|}
\hline & Sampel Testing & $\begin{array}{l}\text { Jumlah } \\
\text { Data }\end{array}$ & & fusion Matrix & & Accuration & $\begin{array}{c}\text { Plot Area Under } \\
\text { ROC }\end{array}$ \\
\hline & $\begin{array}{l}\text { Fakultas : } \\
\text { Mevekili } \\
\text { mahasiswe dari } \\
\text { seluruh Program } \\
\text { Studi }\end{array}$ & 200 & $\begin{array}{l}\text { Class } \\
Y_{a} \\
\text { Tidak }\end{array}$ & $\frac{\mid Y_{a} \text { Tidak }}{|6|} \mid \begin{array}{l}61 \\
\mid 5\end{array}$ & $\begin{array}{l}33 \\
101\end{array}$ & $81 \%$ & $\begin{array}{c}0.9363 \\
\text { Exce/lent } \\
\text { Classification }\end{array}$ \\
\hline 2 & $\begin{array}{l}\text { Mahasisve } \\
\text { Program Studi } \\
\text { Pendidilan Teknik } \\
\text { Bangunan }\end{array}$ & 56 & $\begin{array}{l}\text { Class } \\
Y_{a} \\
\text { Tidak }\end{array}$ & 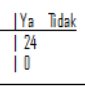 & $\begin{array}{l}10 \\
22\end{array}$ & $\begin{array}{c}82.1429 \\
\%\end{array}$ & $\begin{array}{c}0.9505 \\
\text { Exeel/lent } \\
\text { Classification }\end{array}$ \\
\hline 3 & $\begin{array}{l}\text { Mahasiswe } \\
\text { Program Studi } \\
\text { Pendidikan Teknik } \\
\text { Elektro }\end{array}$ & 53 & $\begin{array}{l}\frac{\text { Class }}{Y_{\mathrm{a} S}} \\
\text { Tidak }\end{array}$ & $\begin{array}{l}\frac{1 Y_{3} \text { Tidak }}{127} \\
10\end{array}$ & $\begin{array}{l}5 \\
21\end{array}$ & $\begin{array}{l}90.566 \\
\%\end{array}$ & $\begin{array}{c}0.9856 \\
\text { Exesellent } \\
\text { Classification }\end{array}$ \\
\hline 4 & $\begin{array}{l}\text { Mahasisue } \\
\text { Program Studi } \\
\text { Pendidikan Teknik } \\
\text { Eleltronika }\end{array}$ & 65 & $\begin{array}{l}\text { Class } \\
\mathrm{Y}_{\mathrm{a}} \\
\text { Tidak }\end{array}$ & $\begin{array}{l}1 Y_{\mathrm{a}} \text { Tidak } \\
125 \\
12 \\
30 \\
\end{array}$ & 8 & $\begin{array}{c}84.6154 \\
\%\end{array}$ & $\begin{array}{c}0.9233 \\
\text { Excellent } \\
\text { Classification }\end{array}$ \\
\hline 5 & $\begin{array}{l}\text { Mahasisue } \\
\text { Pro gram Studi } \\
\text { Pendidikan Teknik } \\
\text { Irfformatika dan } \\
\text { Komputer }\end{array}$ & 82 & $\begin{array}{l}\text { Class } \\
Y_{a} \\
\text { Tidak }\end{array}$ & $\frac{\mid Y_{a} \text { Tidak }}{\mid \|}$ & $\begin{array}{l}14 \\
57\end{array}$ & $\begin{array}{c}82.9268 \\
\%\end{array}$ & $\begin{array}{c}0.9439 \\
\text { Excellent } \\
\text { Classification }\end{array}$ \\
\hline 6 & $\begin{array}{l}\text { Mahasisuse } \\
\text { Program Studi } \\
\text { Pendidilian Tekrik } \\
\text { Mesin }\end{array}$ & 67 & $\begin{array}{l}\frac{\text { Class }}{Y_{a}} \\
\text { Tidak }\end{array}$ & $\begin{array}{l}\mid Y_{a} \text { Tidak } \\
\mid 12 \\
15\end{array}$ & $\begin{array}{l}9 \\
41\end{array}$ & $\begin{array}{c}79.1045 \\
\%\end{array}$ & $\begin{array}{c}0.8944 \\
\text { Good Classification }\end{array}$ \\
\hline 7 & $\begin{array}{l}\text { Mahasisue } \\
\text { Program Studi } \\
\text { Pendidikan Teknik } \\
\text { Otomotf }\end{array}$ & 66 & $\begin{array}{l}\text { Class } \\
Y_{a} \\
\text { Tidak }\end{array}$ & $\frac{\mid Y_{a} T \text { Tdak }}{120}$ & $\begin{array}{l}9 \\
34\end{array}$ & $\begin{array}{c}81.8182 \\
\%\end{array}$ & $\begin{array}{c}0.94217 \\
\text { Exesellent } \\
\text { Classification }\end{array}$ \\
\hline . & $\begin{array}{l}\text { Kahasisves } \\
\text { Program Studi } \\
\text { Pendidikan } \\
\text { Kessajteraan }\end{array}$ & 67 & $\begin{array}{l}\text { Class } \\
Y_{\mathrm{a}} \\
\text { Tidak }\end{array}$ & $\frac{1 Y_{a} \text { Tidak }}{\mid 13} \mid \frac{13}{13}$ & $\begin{array}{l}15 \\
36\end{array}$ & $\begin{array}{c}73.1343 \\
\%\end{array}$ & $\begin{array}{c}0.9002 \\
\text { Exrellent } \\
\text { Classification }\end{array}$ \\
\hline
\end{tabular}

Menurut hasil klasifikasi menggunakan algoritma Naive Bayes Classifier seperti terangkum pada Tabel 3. diterapkan pada Fakultas Teknik Universitas Negeri Padang untuk memetakan atau mengelompokkan mahasiswa yang memiliki kinerja akademik rendah dan membutuhkan proses bimbingan dan konseling, hasilnya diperkirakan akan mendekati seperti Tabel 3.

Tingkat Excellent Classification (sangat baik) tercapai ketika model yang dibuat digunakan untuk mengklasifikasi mahasiswa tingkat Fakultas yang mewakili keseluruhan Prgram Studi, serta Program Studi Pendidikan Teknik Bangunan, Pendidikan Teknik Elektro, Pendidikan Teknik Elektronika, Pendidikan Teknik Informatika dan Komputer, Program Studi Pendidikan Teknik Otomotif dan Pendidikan Kesejahteraan Keluarga.
Program Studi Pendidikan Teknik Elektro. edangkan ketika digunakan untuk mengklasifikasi mahasiswa Program Studi Teknik Mesin tingkat klasifikasi yang didapatkan adalah Good Classification (Baik).

\section{KESIMPULAN}

Berdasarkan analisis dan pengujian yang telah dilakukan, dapat diambil kesimpulan sebagai berikut :

1. Teknik klasifikasi menggunakan Algoritma Naïve Bayes Classifier sangat baik dalam melakukan pemetaan dan mengidentifikasi mahasiswa yang memiliki kinerja akademik rendah dan membutuhkan Bimbingan dan Konseling.

2. Tingkat akurasi yang dihasilkan proses klasifikasi menggunakan algoritma Naïve Bayes sangat ditentukan oleh penentuan dan pemilihan data training.

3. Proses transformasi data dan pemilihan atribut input sangat berpengaruh terhadap output / hasil prediksi.

4. Atribut yang menjadi output pada penelitian ini adalah Butuh BK "Ya" dan "Tidak". Mahasiswa yang masuk Class Butuh BK "Ya" didentifikasi sebagai mahasiswa yang memiliki kinerja akademik rendah dan membutuhkan Bimbingan dan Konseling, sedangkan mahasiswa yang masuk Class Butuh BK "Tidak" adalah mahasiswa yang memiliki kinerja akademik normal dan tidak membutuhkan Bimbingan dan Konseling.

\section{Saran}

Saran yang dapat diberikan untuk pengembangan lebih lanjut adalah sebagai berikut :

1. Pada penelitian ini, penulis hanya mencoba salah satu teknik klasifikasi untuk 
memetakan mahasiswa yang membutuhkan proses Bimbingan dan Konseling yaitu teknik klasifikasi menggunakan Algoritma Naïve Bayes Classifier. Untuk mendapatkan hasil klasifikasi yang lebih baik dapat digunakan beberapa atau penggabungan beberapa teknik klasifikasi seperti penerapan Algoritma CART, ID3, C4.5, Linear Discriminant Analisys serta algoritma klasifikasi yang lain.

2. Untuk mengimplementasikan pola klasifikasi yang dihasilkan dari teknik klasifikasi menggunakan Algoritma Naïve Bayes Classifier tersebut, perlu dilakukan konsultasi lebih lanjut dengan pihak pengambil keputusan, sehingga dapat dipilih pola klasifikasi yang terbaik dalam pemetaan mahasiswa memiliki kinerja akademik rendah dan membutuhkan Bimbingan dan Konseling.

\section{DAFTAR PUSTAKA}

[1] Afen Prana Utama Sembiring, et al, "Analisis Faktor-Faktor yang Mempengaruhi Pengunduran Mahasiswa dengan Aplikasi Data Mining ADD-INS - Studi Kasus Pada STMIK Mikroskil". JSM STMIK Mikroskil. Vol. 14. 139 -146, 2013.

[2] Arif Junanto, "Algoritma Naïve Bayes untuk Mencari Perkiraan Waktu Studi Mahasiswa". Jurnal Teknologi Informasi Dinamik. Vol. 18. 916, 2013.

[3] Arintoko, "Wawancara Konseling di Sekolah". Ed. I. Yogyakarta : ANDI, 2011.

[4] Bustami, "Penerapan Algoritma Naïve Bayes untuk Mengklasifikasi Data Nasabah
Asuransi". Jurnal Informatika. Vol. 8, 2014.

[5] Eko Prasetyo, "Data Mining, Konsep dan Aplikasi Menggunakan Matlab". Ed. I. Yogyakarta : ANDI, 2012

[6] Fajar Astuti Hermawati, "Data Mining". Ed. I. Yogyakarta : ANDI, 2013.

[7] Kadek Suranata, "Pengembangan Model Tutor Bimbingan Konseling Sebaya (peer counseling) untuk Mengatasi Masalah Mahasiswa Fakultas IImu Pendidikan Undiksha". Jurnal Pendidikan Indonesia. Vol. 2. No. 2. 255-263, 2013.

[8] Mujib Ridwan, Hadi Suyono, dan M. Sarosa, "Penerapan Data Mining untuk Evaluasi Kinerja Akademik Mahasiswa Menggunakan Algoritma Naïve Bayes Classifier". Jurnal EECCIS. Vol. 7. 59-64, 2013.

[9] Rizal Amegia Saputra, "Komparasi Algoritma Data Mining untuk Memprediksi Penyakit Tuberculosis (TB) : Studi Kasus Pada Puskesmas Karawang Sukabumi”. Seminar Nasional Inovasi dan Tren (SNIT) 2014. 1-8, 2014.

[10] Sandro Romario. S, "Penerapan Data Mining Pada RSUP DR. Moh Hoesin Sumatera Selatan Untuk Pengelompokan Hasil Diagnosa Pasien Pengguna Asuransi Kesehatan Miskin". Universitas Binadarma 2013, 2013.

[11] Suharsimi Arikunto, "Prosedur Penelitian : Suatu Pendekatan Praktik". Ed. Revisi VI, Jakarta : PT Rineka Cipta, 2006.

[12] Sutirna, "Bimbingan dan Konseling. Pendidikan Formal, Nonformal dan Informal". Ed. I. Yogyakarta : ANDI, 2013 